\title{
What is the future for agroforestry in Italy?
}

\author{
Pierluigi Paris ${ }^{1 *}$, Francesca Camilli ${ }^{2}$, Adolfo Rosati ${ }^{3}$, Alberto Mantino ${ }^{4}$, Giustino Mezzalira ${ }^{5}$, \\ Christina dalla Valle ${ }^{5}$, Antonello Franca ${ }^{6}$, Giovanna Seddaiu ${ }^{7}$, Andrea Pisanelli ${ }^{1}$, Marco Lauteri ${ }^{1}$, \\ Antonio Brunori ${ }^{6}$, Giovanni Antonio Re ${ }^{6}$, Federico Sanna ${ }^{6}$, Giorgio Ragaglini ${ }^{4}$, Marcello Mele ${ }^{8}$, \\ Viviana Ferrario ${ }^{9}$, Paul J. Burgess ${ }^{10}$
}

${ }^{1}$ CNR-IBAF, Porano, Italy ${ }^{2}$ CNR-IBIMET, Firenze, Italy; ${ }^{3}$ Consiglio per la ricerca in agricoltura e I'analisi dell'econimia agraria (CREA), Spoleto, Italy; ${ }^{4}$ Sant'Anna School of Advanced Studies, Pisa, Italy; ${ }^{5}$ Veneto Agricoltura, Legnaro-Italy, ${ }^{6} \mathrm{CNR}$-ISPAAM, Sassari, Italy; ${ }^{7}$ Dep. of Agriculture Sciences, Sassari University, Sassari, Italy; ${ }^{6}$ PEFC-Italy, Perugia, Italy; ${ }^{8}$ Dep. of Agriculture, Food and Environment, University of Pisa, Italy; ${ }^{9}$ Università luav di Venezia, Italy. ${ }^{10}$ Cranfield University, Bedfordshire, United Kingdom

*Corresponding author: Pierluigi Paris, pierluigi.paris@cnr.it

\begin{abstract}
The successful promotion of agroforestry in Italy depends on both a recognition of tradition and the opportunities for innovation. In Italy, agroforestry has traditionally been a key component of landscape management. Complex systems, based on the integration among crops-livestock-fruit/forest trees, provided a wide variety of products (e.g. food, feed, fibers, fuelwood and timber) and other ecosystem services (e.g. soil erosion control and biodiversity preservation). Silvopastoral systems have been used for centuries and are still managed in marginal areas. The integration of fruits trees (in primis olive trees) with crops and grazing was widely practiced and is still profitable. Coltura promiscua was historically developed integrating fruit and forest trees and particularly multifunctional trees (e.g. Juglans regia and Prunus avium) to support vines and intercrops. Building on recent research, projects have also focused on innovation in agroforestry. The adoption of shade tolerant forage species and crops has been studied in silvopastoral and olive systems. Silvopastoral systems can significantly offset the $\mathrm{CO}_{2}$ emissions produced by livestock and shield grazing animals from "heat waves". Integration of fast growing timber trees (like Populus) in arable systems can help reverse the decline in plantation forestry in Italy. Finally, the constraints imposed by the EU agricultural policy, especially the prevalent provisions for monocrops severely limiting the introduction of innovative agroforestry approaches, are discussed. New political measures and certification actions are strongly required.
\end{abstract}

Keywords: sustainable management; marginal areas; silvoarable; silvopastoral; CAP; production certification; physiological ecology 


\section{Introduction}

To address global climate change and food security whilst maintaining or improving the environment, international researchers and policy makers are increasingly promoting agroforestry (IPCC 2000; FAO, 2013; Lasco et al., 2014). Agroforestry is a land use practice integrating woody perennials (trees or shrubs) with crops and/or animals on the same land unit (Nair 1993). In Europe, it is both a traditional land use (Eichhorn et al. 2006) and a focus for innovation. Burgess and Rosati (2018) highlighted that such systems can form a sweet spot between agriculture and forestry. A recent survey carried out in the European AGFORWARD project (www.agforward.eu), estimated a total European area under agroforestry management of about 15 million ha corresponding to $8.8 \%$ of the utilized agricultural land (den Herder et al., 2017).

Italy has the fourth largest area of agroforestry in Europe of 1.4 million ha (Table 1), the second largest area of silvoarable and agroforestry with high value trees and the fourth largest area for livestock agroforestry systems. Italy also contains a wide range of agroclimatic environments ranging from cool Alpine areas to the warm Mediterranean (Metzger et al., 2005), leading to a wide variety of agroforestry systems, which are often rich in biodiversity.

Prior to the 1950s, forests and trees were integral to many Italian land-use systems, as a source of wood and food (fruits and game) and a crucial means for maintaining soil fertility of croplands (Sereni, 1961). However, mechanization, the use of agrochemicals and the increasing cost of agricultural labor have reduced the close links between Italian forests and agriculture (Paris et al., 2001), leading to a progressive simplification of agro-ecosystems, which is a key weakness of current Italian agriculture. However, there are opportunities for implementing both traditional and modern forms of agroforestry that provide both production and environmental benefits (Scherr et al, 2012). Furthermore, the wide range of Italian agroforestry can also create and maintain diversified landscapes that are valuable for recreation and tourism (Gao et al., 2014; Lefebvre et al., 2015).

\section{Objectives and Methodology}

In order to develop appropriate strategies to promote agroforestry in Italy, this paper reviews the pivotal historic role played by agroforestry in the rural economy of Italy and then examines recent innovations and the current and future constraints and opportunities. The review of traditional agroforestry systems in Italy extends previous research by Pardini (2009) and Eichhorn et al. (2006). The examination of innovative agroforestry systems builds largely on the research and development undertaken in the AGFORWARD project between 2014 and 2017 (Burgess and Rosati 2018). In addition, a qualitative narrative review of literature was conducted based on scientific articles collected through ISI WEB of Science and Google scholar, and grey literature known to the authors. The agroforestry found in Italy and the associated innovations are considered in terms of i) silvopastoral systems and those systems focused on ii) olive trees and iii) arable production. Lastly, agroforestry certification is also considered. 


\section{Silvopastoral systems in Italy}

Silvopastoral systems include both the integration of trees on livestock farms and the use of livestock in forests (e.g. forest grazing) and orchards, particularly olive groves. Currently In Italy, there is estimated to be $1,304,600$ ha of land that integrates trees with livestock production, equivalent to about $10.1 \%$ of the utilised agricultural area (Table 1). Historically silvopastoral systems range from forestry grazing to the use of scattered trees in natural pastures. The tree component varies from beech (Fagus silvatica L.) and conifers (mostly larch - Larix decidua Mill.) at high elevations in Alpine and Apennine mountainous areas, to sweet chestnut (Castanea sativa L.) in more humid mountain sites, and mainly oaks (like Quercus ilex L., $Q$. suber L., Q. pubecens Willd. and Q. cerris L.) in the dry Mediterranean areas. Nowadays, most managed silvopastoral systems occur in marginal areas. The benefits of silvopastoral systems in Italy include the mitigation of greenhouse gas emissions, the improvement of livestock adaptability to climate change and the nutritional quality of livestock products (Cassandro et al, 2013; Bernabucci et al., 2014; Segnalini et al., 2013; Nardone et al., 2010). Although overgrazing is a problem for forest regeneration, this can be prevented by managing the grazing pressure through rotational, mixed or precision grazing. A summary of the main silvopastoral systems in three agroclimatic zones, as classified as by Ronchi (2009) is reported below.

Table 1. Extent and distribution of agroforestry in Italy based on LUCAS data categorized according to two systems and relative to the utilised agricultural area (UAA) and total extent (from den Herder et al., 2017)

\begin{tabular}{|c|c|c|c|c|c|c|}
\hline \multirow{2}{*}{$\begin{array}{l}\text { Agroforestry } \\
\text { Type }\end{array}$} & \multicolumn{3}{|c|}{ Primary land cover } & \multirow{2}{*}{$\begin{array}{l}\text { Total } \\
\text { ('000 ha) }\end{array}$} & \multirow{2}{*}{$\begin{array}{l}\text { Proportion } \\
\text { of UAA (\%) }\end{array}$} & \multirow[b]{2}{*}{$\begin{array}{l}\text { Ranking } \\
\text { in EU-27 } \\
\text { in terms } \\
\text { of total } \\
\text { area }\end{array}$} \\
\hline & $\begin{array}{l}\text { Permanent } \\
\text { crops } \\
\text { ('000 ha) }\end{array}$ & $\begin{array}{l}\text { Woodland } \\
\text { ('000 ha) }\end{array}$ & $\begin{array}{l}\text { Shrubland } \\
\text { and } \\
\text { grassland } \\
\text { with sparse } \\
\text { trees } \\
\text { ('000 ha) }\end{array}$ & & & \\
\hline $\begin{array}{l}\text { Agroforestry } \\
\text { with livestock }\end{array}$ & 116.2 & 622.4 & 565.0 & 1303.6 & 10.1 & $4^{\text {th }}$ \\
\hline $\begin{array}{l}\text { Arable } \\
\text { agroforestry }\end{array}$ & 90.3 & 15.8 & 0.0 & 106.1 & 0.8 & $2^{\text {nd }}$ \\
\hline $\begin{array}{l}\text { Total } \\
\text { Utilised } \\
\text { agricultural } \\
\text { area (UAA) }\end{array}$ & 202.2 & 638.2 & 565.0 & $\begin{array}{r}1403.9 \\
12856.0\end{array}$ & 10.9 & $4^{\text {th }}$ \\
\hline
\end{tabular}

\section{Alpine silvopastoral systems}

The areas of wood pasture that remain in the Italian Alps (Rackham and Grove, 2003) are typically semi-extensive and grazed by cattle (Ronchi 2009). The structure includes both lowdensity tree populations, and mosaics of small woods amongst pastures and shrubland (Emanueli and Agnoletti, 2016). On the mountains of Piedmont and Aosta Valley, a traditional system of great landscape and ecological value, although in decline, is the thin larch wood pasture (Garbarino et al., 2011). This system integrates cattle, sheep, pasture and timber 
production (Pardini 2009). The deciduous larch facilitates the spring regrowth of the pasture and provides shelter to livestock from the summer heat. There are over 1000 ha of larch wood pastures at Salten, Bolzano on the Mazzoccolo upland, one of the largest grazed larch woodland in Europe (Emanueli and Agnoletti 2016). Often, the Alpine wood pastures form part of wider transhumance system involving valleys or lowland areas, and in recent years, herds are moved from the Mediterranean climate zones of Tuscany up to the Piedmont Alps to spend the summer months on mountain pastures, called alpeggi (Pardini 2009). In the North-West sector of the Alps, there has also been an increase in goat grazing in forests, because of the growing interest in dairy goat products (Corti 2006).

\section{Apennine silvopastoral systems}

In past centuries, the rural economy of the Apennines was based on agro-silvopastoral transhumance systems, and these led to a reduction in the area of shrubland and forests across central-southern Italy through fire, charcoal production, and grazing of natural vegetation (Caballero et al., 2009). However, after the second half of the 20th century, the reduction in grazing in marginal areas led to a recolonization of shrublands and forests (Santilocchi and D'Ottavio, 2005; Palombo 2013), and in particular the encroachment of Juniperus communis and J. oxycedrus, Spartium junceum and Rosa canina in large tracts of the Central Apennines.

It is considered that there are about 600,000 ha of large-scale grazing systems in the Central Apennines (Caballero et al. 2009), of which about half involves agrosilvopastoral practices (D'Ottavio, personal communication). The main silvopastoral systems on the Apennines are based on indigenous beef breeds, grazing continuously or moved to forest clearings and wood pastures from the end of spring to the beginning of autumn depending on the altitude and environmental conditions (Ronchi 2009).

Longhi et al. (2004) reported that on the northern Apennines, grazing with small herds of sheep and cattle still occurs in clearings of some forest districts. The herds are kept mainly for the benefit of tourists and land conservation rather than for an economic activity (Longhi et al., 2004). The role of sheep grazing in ski lanes and firebreaks lines has received growing interest as a special form of silvopastoralism aiming at preventing shrub ingression and reducing ski lanes management (Argenti et al., 2000; Longhi et al., 2004; Talamucci et al, 1995; Tallarico et al., 2002;). However, many managers consider this practice negatively since animals can dig plants out from shallow soils and, thus, increase the risk of soil erosion.

\section{Mediterranean silvopastoral systems}

Silvopastoral systems are particularly important in the Mediterranean areas of Italy, including the extensive and semi-extensive management for beef cattle, dairy sheep and goats (Ronchi 2009). In Mediterranean areas, the proportion of land area classified as "woods" range from $50 \%$ in Sardinia (1.2 million ha) and $40 \%$ in Calabria to $10 \%$ in Sicily and $7.5 \%$ in Apulia. Among these regions, the greatest diversity and area of silvopastoral systems (wooded pastures, grazed woodlands) is found in Sardinia. In Calabria, Campania, Apulia and Sicily, due to abandonment of pasture, inadequate forest policies, and forest and shrub encroachment, only residual patches of ancient silvopastoral systems are still present. Agnoletti (2013) describes such silvopastoral systems as "historical rural landscapes". 
In the Sardinian silvopastoral systems, livestock (mainly sheep, goats and/or beef cattle but sometimes pigs) typically graze throughout the year in almost all the region, using different feed resources (grasses, shrubs and trees) sometimes on common land. Sedda et al. (2011) estimated that the total area covered by oak-based agro-silvopastoral systems in Sardinia could exceed 400,000 ha. Also, Rossetti et al. (2015) reported that dehesa-like systems in Sardinia cover about 113,000 ha. They are mainly dominated by cork oak, with tree densities ranging from 7 to 250 per hectare and are generally concentrated in the hilly north-eastern and central areas. They are often tilled and sown every two to eight years, to grow annual mixtures for grazing and/or hay production. Such dehesa-like systems are principally grazed by sheep and cattle (Rossetti and Bagella 2014); however, in pure stands of cork oak, grazing is excluded and shrubs are cleared mechanically when encroachment occurs. Beside cork oak forests, Sardinian agrosilvopastoral systems (mostly under private ownership) combine cereals, pastures and forage crops. In the public silvopastoral areas, farmers share grazing rights and agree on the partitioning of the grazing area. Subsidies (e.g. subsidies for compensation of natural limitations) have so far kept most systems viable even if at low-income conditions.

\section{Innovations for Italian silvopastoral systems}

Within the AGFORWARD project, Camilli et al. (2018) examined the positive and negative perceptions of Italian stakeholders in relation to silvopastoral systems. This analysis highlighted concerns related to the effect of agroforestry on pasture productivity, the need to increase the forage availability and the assessment of the appropriate stocking rate to ensure system resilience. The interactions between trees and pasture production have been determined by the capacity of the different components to capture and use light, water and nutrients (Rao et al., 1997; Nissen et al., 1999; Dodd 2005; Koukoura et al., 2009). Generally, annual herbage production decreased as light availability decreased, due to reduced photosynthesis and modification of leaf and tiller anatomy (Devkota and Kemp, 1999). However, the shade provided by trees can increase pasture production at some critical stages in the year (Seddaiu et al., 2018).

Many of the early studies on shade tolerant pasture species focused on the use of grass and legumes as cover crops under orchards or tree hedgerows often using or simulating artificial shade (Watson et al., 1984; Lin et al., 2001; Koukoura et al., 2009). Feldhake and Belesky (2005) indicated that shade tolerant cultivars of selected species would be important for successful silvopastoral management; however, actual experiments using selected species on agroforestry farms are rare. Recently, Mauro et al. $(2011,2014)$ reported a specific adaptation to shaded environments for some legumes such as Medicago rugosa Desr., M. polymorpha L. and Trifolium spumosum. Franca et al. (2016) reported about the adaptation and persistence of a grasslegume mixture for the rehabilitation of a fire prone grazed oak woodland in Sardinia and concluded that the oversowing of well-adapted pasture mixture (Trifolium yanninicum, $T$. brachycalycinum, Medicago polymorpha and Lullium rigidum) facilitated the recovery of the burnt area under grazing management. As part of the AGFORWARD project, the CNR ISPAAM research group completed field trials on shade tolerant pasture legume species on silvopastoral farms. The preliminary results for the site-specific conditions indicated that the most promising species were Trifoliium subterraneum var. Campeda and Ornithopus sativus var. Cadiz. Some 
persistence capability, due to their high levels of hardseededness, may be presumed for Trifolium vesiculosum and M. polymorpha (Franca et al. 2017).

\section{Olive agroforestry systems in Italy}

The olive tree (Olea europaea L.) is the most widely-planted tree crop in Italy covering an area of 1.16 million ha (FAOSTAT 2016). It is also currently the tree crop species most often cultivated in agroforestry systems (Table 2). Its cultivation dates back millennia in Italy, as in the rest of the Mediterranean (Zohary and Hopf, 1994; Besnard et al., 2013), and has profoundly affected the economy and culture of the region (Loumou and Giourga, 2003; Kaniewski et al., 2012). Historically, olive cultivation, as for other fruit trees, was typically an agroforestry system, with sparse trees intercropped with grains and legumes, forages and even vines (Sestini 1963; Lelle and Gold 1994), as described by Columella in "De re rustica". Such olive agroforestry systems remained virtually unchanged for centuries and even today the Italian land registry (cadaster) classifies these lands as "seminativo arborato" (arable land with trees). When the understory was not cultivated, the orchard provided pasture for animals which, in turn, controlled weeds and provided fertilization for the orchards (Vannucci, 2009). As an evergreen species, olive pruning materials also provided forage.

Table 2. Area of cultivation of fruit trees in agroforestry systems in Italy for selected years between 1910 and 1980 (Italian National Institute of Statistics (ISTAT), data published by Agnoletti 2013).

\begin{tabular}{lrrrrrrrrrr}
\hline Year & \multicolumn{8}{c}{ Area of fruit trees in agroforestry systems ('000 ha) } \\
\cline { 2 - 10 } & Vine & Olive & \multicolumn{1}{c}{ Apple } & Pear & Peach & Plum & Almond & Walnut & Fig \\
\hline 1910 & 3570 & 1799 & na & na & na & na & na & na & na \\
1930 & 2974 & 1355 & na & na & na & na & na & na & na \\
1940 & 2963 & 1360 & 1595 & 1908 & 1142 & 898 & 760 & 775 & 1273 \\
1950 & 2899 & 1437 & 1523 & 1749 & 1062 & 874 & 320 & 689 & 1342 \\
1960 & 2578 & 1394 & 405 & 432 & 182 & 112 & 457 & 148 & 264 \\
1970 & 702 & 1280 & 192 & 220 & 104 & 71 & 413 & 98 & 130 \\
1980 & 445 & 1080 & 62 & 83 & 47 & 23 & 265 & 54 & 46 \\
\hline
\end{tabular}

After 1980, ISTAT has no longer distinguished between specialized and agroforestry cultivation of fruit trees.

Na: not available

The area of recorded olive agroforestry (i.e. olive trees intercropped with other crops and/or grazed) in Italy declined from 1.8 million ha in 1910 to 1.08 million ha in 1980 (Table 3), associated with increasingly specialized orchards, with closer spaced trees, to increase production (Brugnoli and Varanini, 2005). This trend certainly continued after 1980, but there are no current data on the present extent of olive agroforestry. Despite this trend, olive orchards in Italy are still in great part managed with traditional cultivars and large trees, often planted at low and irregular densities and this makes it difficult to precisely estimate the actual area covered by olive trees. Even so, it is estimated that there are several hundred thousand hectares of relatively sparse olive trees in Italy that are, or could be, intercropped with other crops and/or grazed. 
Innovations for olive agroforestry

In recent decades, green mulching in olive orchards has been increasingly recommended and adopted, both to prevent soil erosion and soil degradation and to increase biodiversity. Surprisingly, there has been minimal focus on using economically viable crops as green mulches, perhaps because of cultural perceptions associated with intercropping. By contrast, Rosati et al $(2009 ; 2011)$ argue that there are revenue benefits of using marketable crops as long as they are compatible with modern orchard management. Since, in Italy, olive trees are protected, because of their landscape value and removing them is mostly illegal, the low profitability of olive systems implies a risk of abandonment for large areas. Turning the orchards into more productive and economically valuable agroforestry systems may contribute to their preservation and the maintenance of attractive olive landscapes that support tourism.

There have been some recent attempts to design modern olive agroforestry systems. Possible crops to be intercropped with olive trees need to be compatible with modern orchard management, including widely used crops or innovative ones for highly profitable market niches connected to eco-tourism. Preference should be for perennial crops, which offer greater soil erosion control benefits than annual crops (Vallebona et al., 2016). There is also interest in introducing medicinal species and species that encourage bees and other pollinator species.

Growing alfalfa (Medicago sativa L.) in olive orchards in Italy is still relatively common. Mantino et al. (2016) examined alfalfa grown in wide-spaced (i.e. $5 \mathrm{~m} \times 10 \mathrm{~m}$ ) olive orchards in Tuscany, and observed that the nutritive value of the alfalfa was unaffected by the trees despite lower yields than in open field conditions.

Alternative intercrops also include naturally occurring edible vegetation for gourmet markets (Rosati et al. 2009; 2011). Examples are species of arugula (Diplotaxis spp.) and species from the sunflower family like sow thistle (Sonchus oleraceus) and wild chicory (Cichorium intybus). These species were historic components of the Mediterranean diet and, although recently neglected, if their cultural and health value was identified and promoted, they could be profitable crops. This could be particularly interesting for the 20,000 farms in Italy that integrate farming with tourism activities (agro-tourism), where such products can be introduced and explained directly to the consumers.

Recent research proposed the cultivation of a perennial wild asparagus (Asparagus acutifolius L.) as an understory crop in olive orchards (Rosati 2001; 2009; 2011; Mantovani et al., 2016). As a perennial crop, asparagus can help reduce soil erosion. The spears of wild asparagus have been traditionally consumed in the Mediterranean area (Venezia et al., 1993; Fiori et al., 2001; Adam 2004; Aliotta et al., 2004; Pieroni et al., 2005), and they remain a valuable product as Asparagus acutifolius (as opposed to Asparagus officinalis) is not widely grown (Rosati, 2001). The cultivation of wild asparagus, however, is possible (Venezia et al, 1993; Rosati and Falavigna, 2000; Rosati et al., 2005; Benincasa et al., 2007; Rosati 2008) and it can be used as an intercrop in olive orchards (Rosati et al., 2012b; 2012a; 2012c). The drought tolerance of the Mediterranean wild asparagus also makes this crop particularly suitable for environments where olive trees are typically grown. 
Olive orchards can also be combined with poultry systems, like free range chickens, to weed and fertilize the trees (Rosati et al., 2009, 2012a, 2012b; 2012c; 2014). The chickens under the trees feel better protected from predators and the trees encourage wider ranging as chickens venture further away from their sheds, thus foraging and benefitting from the pasture more than without trees (Dal Bosco et al., 2014). The enhanced foraging can also improve chicken meat quality (Dal Bosco et al., 2016). A life cycle assessment (LCA) by Paolotti et al (2016) also showed that combining free range chicken with olive orchards brings about environmental benefits, partly due to the chickens improving fertilization and weed control. Rosati et al. (2009, 2012a, 2012b, 2012c) have also examined and produced a video describing an agroforestry system combining olives, wild asparagus and chickens. They observed that the mature asparagus plants are prickly and do not get damaged by the birds.

\section{Agroforestry for arable farms in Italy}

The area of arable land in Italy has declined from 13 million ha in 1950 to 7 million ha in 2010 (Table 3), associated with the industrialization of agriculture, socio-economic change and the globalization of agricultural markets. This reduction in arable area has meant that a higher proportion of arable crop products is now imported into Italy. In addition, much of the remaining arable land is found in lowland Mediterranean climates where crop yields are particularly susceptible to climate change (Burlando and Rosso 2002; Giorgi and Lionello 2008). The land use changes in arable areas have had contrasting effects on the tree cover. In many marginal areas, the land has been abandoned and there has been natural tree regeneration. In other arable areas, trees scattered across fields or along field margins have been removed with negative effects for biodiversity, soil protection and wood production.

Table 3. Area of forestry and different types of agricultural land and the number of livestock in Italy in 1861, 1950 and 2010 (Source, Italian National Institute of Statistics, ISTAT).

\begin{tabular}{|c|c|c|c|c|c|}
\hline \multirow[t]{2}{*}{ Year } & \multicolumn{3}{|c|}{ Agriculture } & \multirow{2}{*}{$\begin{array}{l}\text { Forestry } \\
\text { (million ha) }\end{array}$} & \multirow{2}{*}{$\begin{array}{l}\text { Livestock (Cattle, } \\
\text { pig, sheep, goat, } \\
\text { and equine) } \\
\text { (million head) }\end{array}$} \\
\hline & $\begin{array}{l}\text { Arable land } \\
\text { (million ha) }\end{array}$ & $\begin{array}{l}\text { Pasture land } \\
\text { (million ha) }\end{array}$ & $\begin{array}{l}\text { Permanent crops } \\
\text { (million ha) }\end{array}$ & & \\
\hline 1861 & 12.70 & 5.70 & 2.30 & 5.63 & 16.78 \\
\hline 1950 & 13.10 & 5.10 & 2.40 & 5.67 & 27.16 \\
\hline 2013 & 6.80 & 3.34 & 2.26 & $10.98^{\mathrm{a}}$ & 24.82 \\
\hline
\end{tabular}

${ }^{a}$ INFC 2016 (www.sian.it)

As in the rest of Europe, farmers with arable land in Italy receive Pillar I and Pillar II payments from the Common Agricultural Policy (CAP). However, despite the multiple public benefits provided by trees, the level of Pillar I payment received by farmers for arable land declines as the tree density increases (Figure 1) (Perali, 2004). Since 1992, farmers have been able to receive Pillar II payments for establishing buffer strips to reduce water contamination, and broadleaved tree plantations either for valuable hardwood plantations (e.g. walnuts, wild cherry) or for bioenergy plantations with fast growing tree species such as Populus spp., Salix spp and Robinia pseudoacacia L. (Facciotto et al, 2015). However, the majority of farmers are not attracted to these systems because of the poor financial returns and the depressed Italian market for high value timber. 


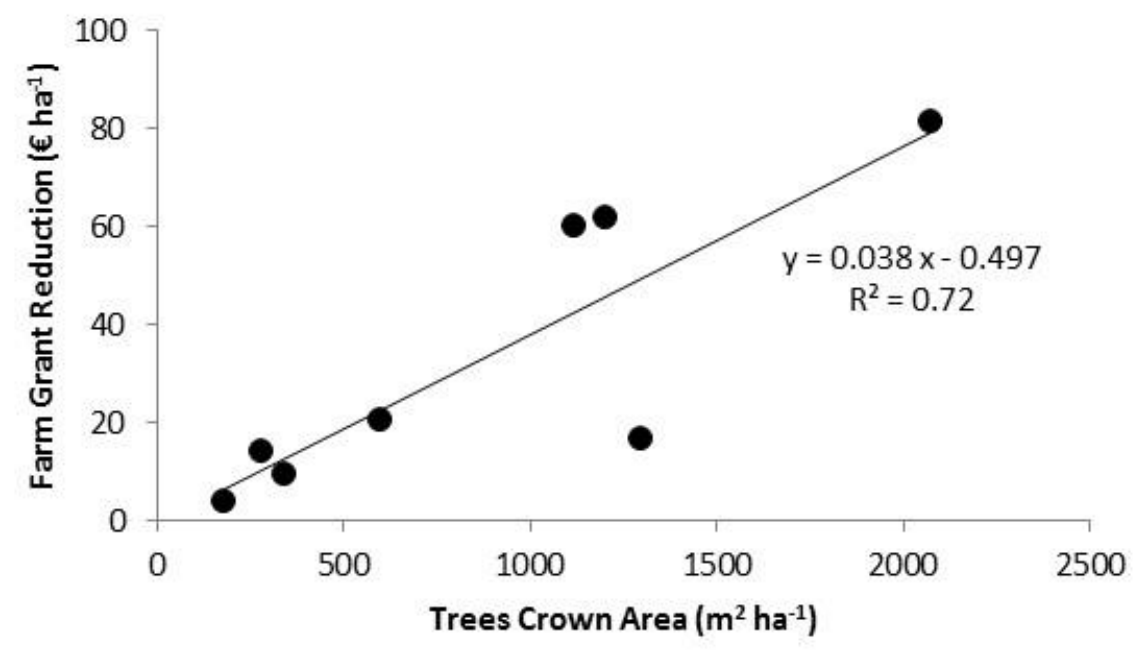

Fig 1. Reduction in Pillar $1 \mathrm{EU}$ single farm payments in relation to the area occupied by trees in agricultural areas, based on crown projection in Italy (Perali, 2011)

Coltura promiscua (literally promiscuous cultivation) is a commonly used term in Italy indicating the typical association of trees, vines and arable crops (Meynier 1958; Zimmermann 1981; Meeus et al., 1990; Pinto Correia and Vos, 2005; Zimmermann 2006). Such systems were also found in other regions of Southern Europe characterized by very wet winters and hot summers e.g. in northern Portugal (Stanislawski 1970), in the Basque region of Spain, and areas of Southern France (Lavignac 2001). In many Italian regions the coltura promiscua was so widespread that in 1929 in Tuscany, 97.2\% of the land has been reported as being dedicated to coltura promiscua and only $2.8 \%$ to specialized crops (Pazzagli 1979).

One system involved the planting of scattered trees in fields to sustain one or more vines. In other areas, fields were divided into long arable strips separated by rows of vines trained on the trees (Fig 2). The branches of the vines were woven from one tree to another along the same row with intercrops of cereals, vegetables or forage. Desplanques (1959) defined this system a "vertical mixed cropping". This traditional agroforestry system was regionally practiced under different names: alberata in Tuscany, Umbria and Marche, arbustato in the Naples hinterland, piantata in the Po valley, creating diverse veritable "landscapes of trees" (Meynier 1958).

According to Babo 1866, the coltura promiscua was a perfect multifunctional agricultural system providing several services from the same field: food (grains, wine and fruits), feed (hay and tree fodder), fuel (wood) and building materials (timber). Trees provided shelter for birds and small game, reduced hailstorm damage and excessive solar radiation on the vines, limiting transpiration and reducing drought stress. Prior to the 1950s, these systems were estimated to contribute to more than half of domestic timber and wood production in Italy (13 million $\mathrm{m}^{3}$ roundwood), compared to forest production of 10 million $\mathrm{m}^{3}$ (Mezzalira 1999). After the 1960s and the associated modernization of Italian agriculture, coltura promiscua virtually disappeared (Sereni 1957; Desplanques 1959; Gambi 1973) as the "outdated" rows of vines trained on the 
trees were perceived as an obstacle to agricultural machines and were eradicated from the fields. However, some relicts of tree rows and vines can still be found (Fig 3) and they are increasingly recognized for their heritage value as a living archive of the coltura promiscua historical landscape (Ferrario, 2012). Although the coltura promiscua cannot be revived as it was in the past, it could provide a basis to understand the mutual behavior of different crops and new forms of multifunctional and sustainable agriculture systems (Lang et al. 2018).

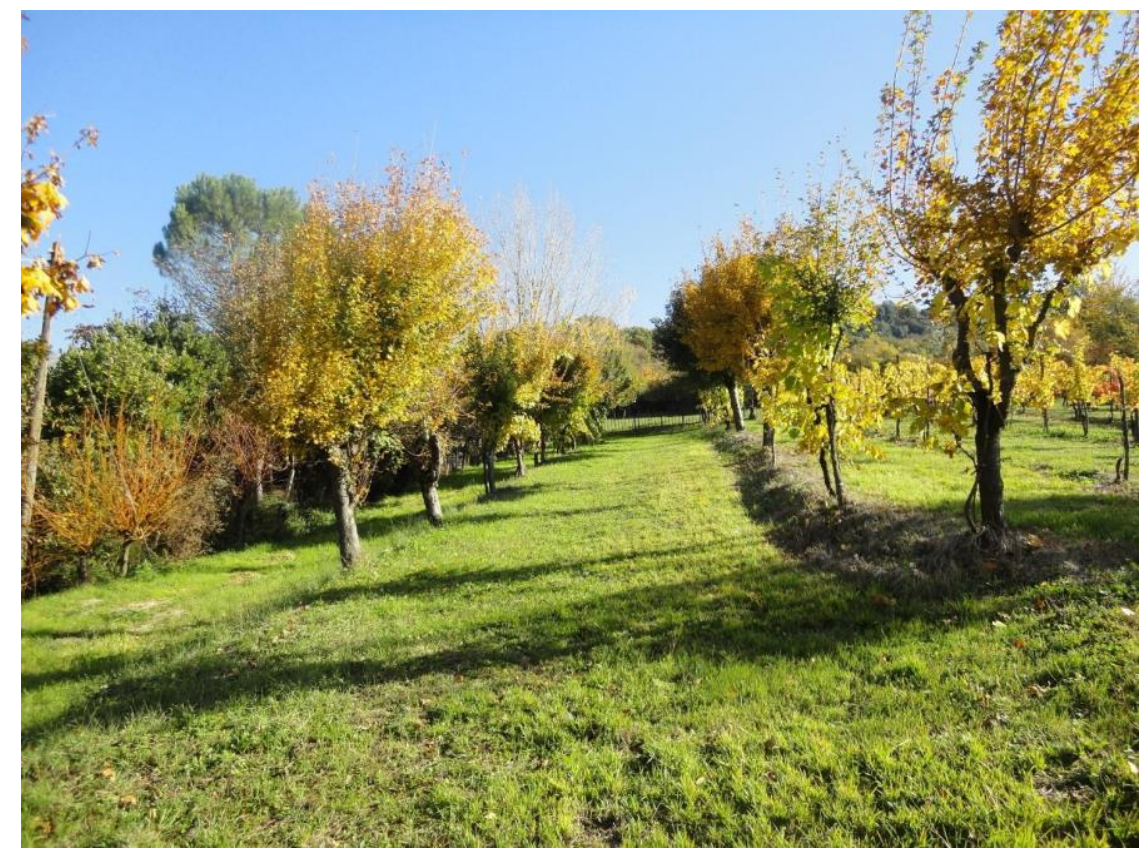

Fig 2. Coltura promiscua in a hilly area of central Italy with maple trees (Acer campestris L.) along terrace ridges supporting grapevine and with hay intercropping in between the trees (photo by P. Paris)

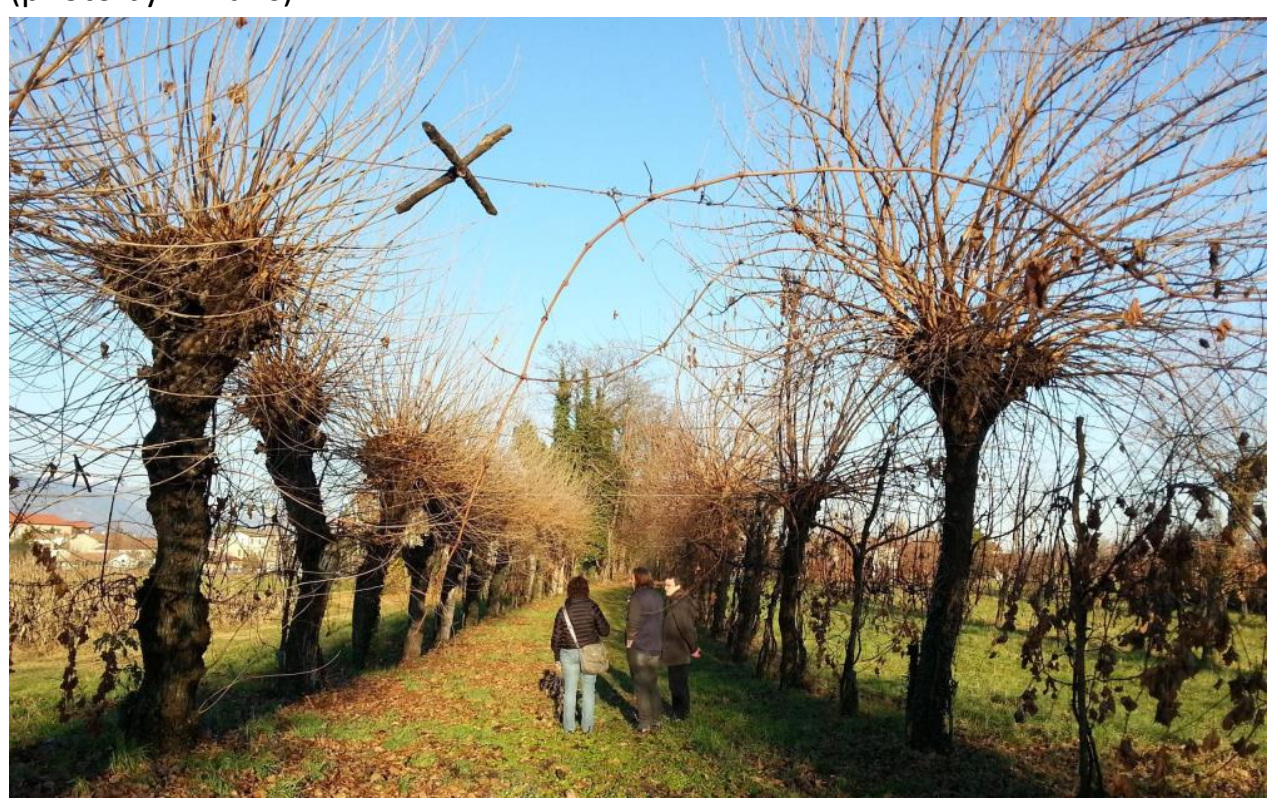

Fig 3. Coltura promiscua in the fertile alluvial area of northern Italy with poplar trees supporting grapevine. Trees crown is periodically lopped for reducing the shade on the understory. Pruning was used in the past for fuelwood, hay (fresh shoots with leaves), and basketwork (photo by $M$. M. Turato, 2013). 


\section{Agroforestry innovations for arable systems}

Agroforestry on arable lands can improve land productivity, reduce pollution and address climate change by sequestering more carbon than conventional arable systems. CNR-IBAF, Veneto Agricoltura, the University of Pisa and the Sant'Anna School of Advanced Studies in Pisa have investigated the effects of tree buffer strips along field margins and drainage systems and silvoarable systems on wood production and environmental benefits (Fig 4). Borin et al. (2010) reported the positive effects of such systems on reducing pollutants in runoff water, reducing nitrogen leaching and increasing carbon sequestration. Although the wood production component of the system was often unprofitable (Borin et al. 2010), the use of fuelwood for self-consumption is often practiced and difficult to evaluate.

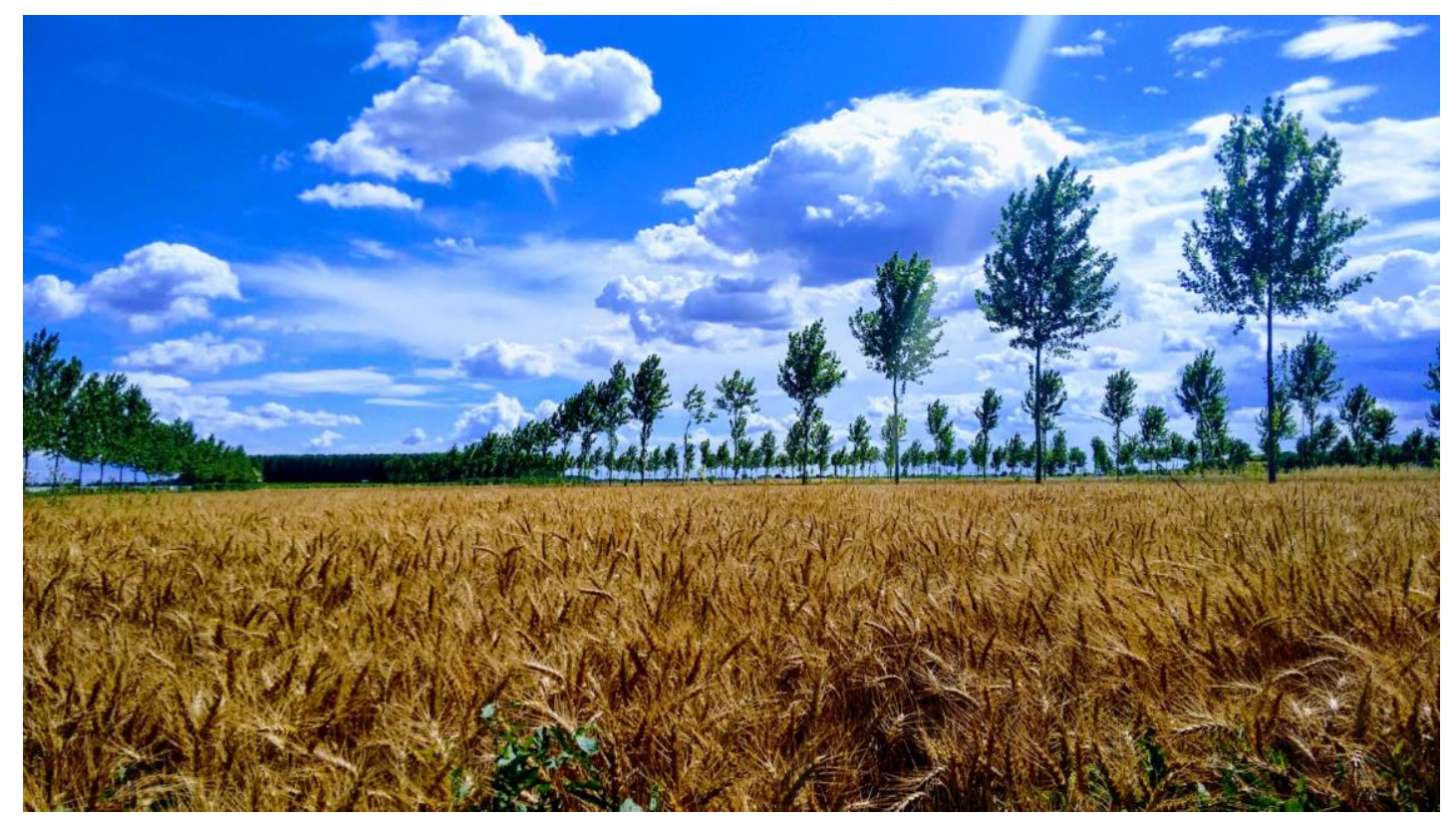

Fig 4. Linear planting of poplar and oak along drainage ditches in Masi (Padova), Italy (photo by A. Mantino, 2018).

There is a global demand for high quality timber from hardwood tree species; however, this typically requires soils with good fertility, which creates competition with food crops (Pra et al., 2016). Early silvoarable research in Italy focused on walnut and the competition between young trees and crops for soil nutrients and water (Paris et al. 1995, 1998, 2005; Pini 1999). Regarding light competition, Paris et al. (2013) showed that tree shade can be strongly detrimental to crop yields; however, modelling research in France suggests that the combination of high value walnuts with arable crops could still be profitable (Palma et al. 2007). In Italy, experimental plots on poplar-oak silvoarable systems, set up within the AGFORWARD project, demonstrated that the initial timber quality of poplar trees is not negatively affected by the wide tree spacing required by agroforestry (Paris et al. 2016). Chiti et al. (2012) reported that approximately $70 \%$ of the soil carbon stored on arable land in Italy occurs within the top $30 \mathrm{~cm}$. Cardinael et al. (2016) found an average soil organic carbon accumulation of $0.24(0.09-0.46) \mathrm{Mg} \mathrm{Cha}^{-1} \mathrm{yr}^{-1}$ at a depth of $30 \mathrm{~cm}$ in silvoarable sites in France. If similar responses were found in Italy, then turning arable lands into silvoarable agroforestry could be a means of increasing national carbon sequestration. 


\section{Agroforestry certification}

Interest is growing in extending the scope of sustainable forest management certification to "trees outside the forest" (ToF) (de Foresta et al., 2013; PEFC 2015). Such agroforestry certification will require the establishment of sustainable management criteria and guidelines for agroforestry in Europe in a similar way to agriculture and forestry. It could also form the basis of future certification of products from sustainably managed agroforestry systems, which could increase the awareness of the social and environmental benefits of agroforestry by European consumers.

In Italy, the National Governing Body of the Programme for the Endorsement of Forest Certification schemes (PEFC) in 2015 and 2016 developed a national standard focused on tree plantations, that includes some ToF management systems close to agroforestry. However, agroforestry certification will be available only after the approval at the international level of the PEFC SFM meta-standard, expanding the scope and including a new appendix for ToF interpretation. A new national level of agroforestry or ToF standard would also require the implementation of a pilot agroforestry certification to explore critical issues identified during PEFC ToF scoping phase and clearly sharing practical feedback with PEFC from project implementation.

\section{Conclusions}

Recent research on agroforestry in Italy has highlighted its historic and cultural importance, and its capacity to address current concerns by combining climate-smart food production with enhanced environmental benefits and opportunities for high value timber production. There are important biodiversity benefits from preserving traditional plant cultivars and livestock breeds found within traditional silvopastoral systems. Well-managed wood pasture systems also provide opportunities to minimize land abandonment. However agroforestry often requires additional management inputs compared to conventional farming, and hence in view of its wider societal benefits, we argue that agroforestry in Italy deserves to be supported through the CAP and associated rural development measures. As reviewed by Mosquera-Losada et al (2018) and Santiago-Freijanes et al. (2018), the CAP support for agroforestry is dispersed in many different measures and the profile of agroforestry would be increased if these measures were brought together. Local and national policy makers in Italy can also promote the adoption and maintenance of agroforestry by minimizing the administrative barriers associated with tree management on farm land.

\section{Acknowledgement}

We acknowledge funding for this research from the European Community's Seventh Framework Program under Grant Agreement No.613520 (Project AGFORWARD). 


\section{References}

Adam D (2004) L'asperge sauvage: de la recolte spontanee a une production commerciale. Infos-Ctifl 207:43-45

Agnoletti M (2013) Italian historical rural landscapes: dynamics, data analysis and research findings. In: Agnoletti M (ed) Italian Historical Rural Landscapes, Springer Netherlands, pp 3-87

Aliotta G, Aceto S, Farina A, Gaudio L, Rosati A, Sica M, Parente A (2004) Natural history, cultivation and biodiversity assessment of asparagus. In: Research Advances in Agriculture and Food Chemistry, Global Research-Network, pp 1- 12

Argenti G, Merati M, Staglianò N, Talamucci, P (2000) Herb sowing and evolution in ski lanes in alpine areas (Insediamento ed evoluzione di inerbimenti tecnici di piste da sci in ambiente alpino). Rivista di Agronomia 34, 1 (In Italian)

Babo A (1866) Bericht über die im Auftrage des k k Ministeriums für Handel und Volkswirtschaft unternommene Bereisung der Weinbau treibenden Kronländer Österreichs. I. Kroatien, Dalmatien, Istrien, Venetien, Tirol, Krain, Steiermark. Verlag C. Gerold's Söhne, Wien

Benincasa P, Tei F, Rosati A (2007) Plant density and genotype effects on wild asparagus (Asparagus acutifolius L.) spear yield and quality. HortScience, in press

Bernabucci U, Lacetera N, Baumgard LH, et al (2010) Metabolic and hormonal acclimation to heat stress in domesticated ruminants. Animal 4:1167-1183. doi: 10.1017/S175173111000090X

Bernabucci U, Biffani S, Buggiotti L, Vitali A, Lacetera N Nardone A (2014) The effects of heat stress in Italian Holstein dairy cattle. J. Dairy Sci. 97:471-486. doi: 10.3168/jds.20136611

Besnard G, Khadari B, Navascués $M$, Fernández-Mazuecos $M$, El Bakkali A, Arrigo N, Baali-Cherif D, Brunini-Bronzini de Caraffa V, Santoni S, Vargas P, Savolainen V (2013) The complex history of the olive tree: from Late Quaternary diversification of Mediterranean lineages to primary domestication in the northern Levant. Proc Biol Sci. doi:10.1098/rspb.2012.2833

Borin M, Passoni M, Thiene M, Tempesta T (2010) Multiple functions of buffer strips in farming areas. Eur J Agron 32: 103-111. doi: 10.1016/j.eja.2009.05.003

Brugnoli A, Varanini GM (2005) Olivi e olio nel medioevo italiano (Vol. 29), CLUEB, Bologna

Burgess PJ, Rosati A. (2018) Advances in European Agroforestry: results from the AGFORWARD project. Agroforest Syst 92:801-810. https://doi.org/10.1007/s10457018-0261-3

Burlando P, Rosso R (2002) Effects of transient climate change on basin hydrology. 1. Precipitation scenarios for the Arno River, central Italy. Hydrol Process 16:1151-1175. doi: 10.1002/hyp.1055

Caballero R, Fernandez-Gonzalez F, Perez Badia R, Molle G, Roggero PP, Bagella S, D'Ottavio P, Papanastasis, VP, Fotiadis G, Sidiropoulou A, Ispikoudis J (2009) Grazing systems and biodiversity in Mediterranean áreas: Spain, Italy and Greece. Pastos, 39: 9-154

Camilli F, Pisanelli A, Seddaiu G, Franca A, Bondesan V, Rosati A, Moreno GM, Pantera A, Hermansen JE, Burgess PJ (2018) How local stakeholders perceive agroforestry systems: an Italian perspective. Agrofor Syst. https://doi.org/10.1007/s10457-017$\underline{0127-0}$

Cardinael R, Chevallier T, Barthès BG, et al (2015) Impact of alley cropping agroforestry on stocks, forms and spatial distribution of soil organic carbon - A case study in a Mediterranean context. Geoderma 259-260:288-299. doi: 10.1016/j.geoderma.2015.06.015

Cassandro M, Mele M, Stefanon B (2013) Genetic aspects of enteric methane emission in livestock ruminants. Ital J Anim Sci 12:73. doi:10.4081/ijas.2013.e73 
Chiti T, Gardin L, Perugini L, et al (2012) Soil organic carbon stock assessment for the different cropland land uses in Italy. Biol Fertil Soils 48:9-17. doi: 10.1007/s00374-011-0599-4

Corti M (2006) Risorse silvo-pastorali, conflitto sociale e sistema alimentare: il ruolo della capra nelle comunità alpine della Lombardia e delle aree limitrofe in età moderna e contemporanea. In: SM Annali di S. Michele, 19:235-340

D'Ottavio P, Scotton M, Ziliotto U, (2000) Legumes in mountain pastures of Monti Sibillini (Central Apennines, Italy) grazed by sheep. Grassland Science in Europe 5:286-288

D'Ottavio R, Scotton M, Ziliotto U (2004) Forage selection by sheep in extensive grazing systems in the Monti Sibillini National Park (Central Apennines, Italy). Options Méditerranéennes. Serie A: Séminaires Méditerranéens 61:189-192

Dal Bosco A, Mugnai C, Mattioli S, Rosati A, Ruggeri S, Ranucci D., Castellini C (2016) Transfer of bioactive compounds from pasture to meat in organic free-range chickens. Poultry Science 00:1-8. doi:10.3382/ps/pev383

de Foresta H, Somarriba E, Temu A, Boulanger D, Feuilly H, GauthierM(2013) Towards the assessment of trees outside forests forest. Resources assessment working paper 183. FAO, Rome.

den Herder M, Moreno G, Mosquera-Losada RM, et al (2017) Current extent and stratification of agroforestry in the European Union. Agric Ecosyst Environ 241:121-132. doi: 10.1016/j.agee.2017.03.005

Desplanques H (1959) II paesaggio della coltura promiscua in Italia. Rivista Geografica Italiana LXV: 29-64

Devkota NR, Kemp PD (1999) Morphological aspects of pasture species in the shade in relation to various management practices under silvopastoral systems. J. Inst. Agric. Anim. Sci. $19-20: 1-26$

Dodd IC (2005) Root-to-shoot signalling: Assessing the roles "up" in the up and down world of long-distance signalling in planta. Plant Soil 274: 251-270. doi:10.1007/s11104-0040966-0

D'Ottavio P, Scotton M, Ziliotto U (2000) Legumes in mountain pastures of Monti Sibillini (Central Apennines, Italy) grazed by sheep. Grassl Sci Eur 5:286-288

Eichhorn MP, Paris P, Herzog F, Incoll LD, Liagre F, Mantzanas K, Mayus M, Moreno G, Papanastasis VP, Pilbeam DJ, Pisanelli A, Dupraz C (2006) Silvoarable Systems in Europe: past, present and future prospects. Agroforestry Systems 67: 29-50.

Emanueli F, Agnoletti M (2016) History and Traditional Management of Italian Wood Pastures. In: Agnoletti M, Emanueli F (eds) Biocultural Diversity in Europe. Springer International Publishing, Cham, pp 141-155

Facciotto G, Minotta G, Paris P, Pelleri F (2015) Tree farming, Agroforestry and the New Green Revolution. A necessary alliance. O. Ciancio (Ed.), Proceedings of the II International Congress of Silviculture, Vol. II, pag.658-69. Italian Academy of Forest Sciences, FirenzeItaly, 26-28 nov. 2014; ISBN 978-88-87553-21-5

FAO (2013) Advancing Agroforestry on the Policy Agenda: A guide for decision-makers, by G. Buttoud, in collaboration with O. Ajayi, G. Detlefsen, F. Place \& E. Torquebiau. Agroforestry Working Paper no. 1. Food and Agriculture Organization of the United Nations. FAO, Rome

FAOSTAT (2013) Available at http://faostat3.fao.org/. Accessed on 15 February 2016

Feldhake CM, Belesky DP (2005) Photosynthetically active radiation use efficiency of Dactylis glomerata in a hardwood silvopasture. North American Agroforestry Conference, CDROM, June 2005

Ferrario V (2012) Aratorio arborato vitato. Il paesaggio agrario della coltura promiscua tra fonti catastali e fonti cartografiche. In: Bortolami S Mengotti C (eds) Antico e sempre nuovo. L'agro centuriato a nord est di Padova dalle origini all'età contemporanea. Cierre edizioni, Verona 
Fiori PP, Giola M, Ledda M, Tedde M (2001) Valorizzazione dell'asparago selvatico (A. acutifolius L.). L'Informatore agrario, 50: 47.

Franca A, Caredda S, Sanna F, Fava F, Seddaiu, G (2016) Early plant community dynamics following overseeding for the rehabilitation of a Mediterranean silvopastoral system. Grassl Sci 62: 81-91. doi:10.1111/grs.12114

Franca, A., Porqueddu, C., Sanna, F., Seddaiu, G., Re, G.A. (2017). Lessons learnt for grazed oak wood pasture in Sardinia, Italy, Contribution to Deliverable 2.5 in the AGFORWARD project. 13 November 2017. http://www.agforward.eu/index.php/en/grazed-oakwoodlands-in-sardinia.html

Gambi L (1973) Critica ai concetti geografici di paesaggio umano. In: Id. Una geografia per la storia. Einaudi, Torino, pp 151-168

Gao J, Barbieri C, Valdivia C (2014) Agricultural Landscape Preferences: Implications for Agritourism Development. J Travel Res 53:366-379. doi: 10.1177/0047287513496471.

Garbarino M, Lingua E, Martinez Subirà M, Motta R (2011) The larch wood pasture: structure and dynamics of a cultural landscape. Eur J For Res 130:491-502. doi: 10.1007/s10342010-0437-5

Giorgi F, Lionello P (2008) Climate change projections for the Mediterranean region. Glob Planet Change 63:90-104. doi: 10.1016/j.gloplacha.2007.09.005

IPCC (2000) Land Use, Land-Use Change and Forestry. Watson RT, Noble IR, Bolin B, Ravindranath NH, Verardo DJ, Dokken DJ (Eds.) Cambridge University Press, UK, pp 375

ISTAT Italian National Institute of Statistics. http://www.istat.it/it/ Last accessed on 16.07.2018

Kaniewski D, Van Campo E, Boiy T, et al (2012) Primary domestication and early uses of the emblematic olive tree: Palaeobotanical, historical and molecular evidence from the Middle East. Biol Rev 87:885-899. doi:10.1111/j.1469-185X.2012.00229.x

Koukoura Z, Kyriazopoulos AP, Parissi ZM (2009) Growth characteristics and nutrient content of some herbaceous species under shade and fertilization. Spanish J Agric Res 7:431-438. doi: $10.5424 / \mathrm{sjar} / 2009072-433$

Lang, C.P., Merkt, N., Geilfus, C.M., Graeff-Hönninger, S., Simon, J., Heinz Rennenberg, H., \& Zörb, C. (2018) Interaction between grapevines and trees: effects on water relations, nitrogen nutrition, and wine. Archives of Agronomy and Soil, Science. doi: 10.1080/03650340.2018.1493197

Lasco RD, Delfino RJP, Catacutan DC, et al (2014) Climate risk adaptation by smallholder farmers: The roles of trees and agroforestry. Curr Opin Environ Sustain 6:83-88. doi: 10.1016/j.cosust.2013.11.013

Latawiec AE, Strassburg BBN, Valentim JF, et al (2014) Intensification of cattle ranching production systems: socioeconomic and environmental synergies and risks in Brazil. Animal 8:1255-1263. doi: 10.1017/S1751731114001566

Lavignac G (2001) Cépages du Sud-Ouest. Mémoire d'un ampélographe. Editions du Rouergue, Rodez

Lefebvre M, Espinosa M, Gomez y Paloma S, et al (2015) Agricultural landscapes as multi-scale public good and the role of the Common Agricultural Policy. J Environ Plan Manag 58:2088-2112. doi: 10.1080/09640568.2014.891975

Lelle MA, Gold MA. (1994) Agroforestry Systems for Temperate Climates: Lessons from Roman Italy Forest \& Conservation History 38 118-26

Lin CH, Mcgraw ML, George MF, Garrett HE (2001) Nutritive quality and morphological development under partial shade of some forage species with agroforestry potential. Agrofor Syst 53:269-281. doi:10.1023/A:101332340983

Longhi F, Pardini A, Ghiselli L, Tallarico R (2004) Comparison of terrestrial and aerial oversowing of ski lanes grazed by sheep in the northern Apennines (Central Italy). In: Proceedings of an international congress on silvopastoralism and sustainable management "Silvopastoralism and sustainable land management", Lugo, Spain, pp. 152-153 
Loumou A, Giourga C (2003) Olive groves: "The life and identity of the Mediterranean". Agriculture and Human Values 20:87-95

Mantino A, Ragaglini G, Tozzini C, Cappucci A, Mele M, Bonari E (2016) Yield and nutritive value of alfalfa (Medicago sativa L.) in an olive (Olea europaea L.) alley-cropping practice. Book of abstract 3rd European Agroforestry Conference, Montpellier, Franc. ISBN: 9782-87614-717-1, EAN: 9782876147171. Page: 403-406

Mantovani D, Benincasa P, Rosati A (2016) Olive (Olea europaea L.) and wild asparagus (Asparagus acutifolius L.) agroforestry system: asparagus performance and its best positioning in the olive orchard. In: Book of abstract 3rd European Agroforestry Conference, Montpellier, Franc. ISBN: 978-2-87614-717-1, EAN: 9782876147171. Page: 229-231.

Mauro RP, Occhipinti A, Longo AMG, Mauromicale G (2011) Effects of Shading on Chlorophyll Content, Chlorophyll Fluorescence and Photosynthesis of Subterranean Clover. J Agron Crop Sci 197:57-66. doi:10.1111/j.1439-037X.2010.00436.x

Mauro RP, Sortino O, Dipasquale M, Mauromicale G (2014) Phenological and growth response of legume cover crops to shading. J Agric Sci 152:917-931. doi:10.1017/S0021859613000592

Meeus JHA, Wijermans MP, Vroom MJ (1990) Agricultural landscapes in Europe and their transformation. Landscape and Urban Planning 18: 289-352 doi:10.1016/01692046(90)90016-U

Metzger MJ, Bunce RGH, Jongman RHG, Mücher CA, Watkins JW (2005) A climatic stratification of the environment of Europe. Global Ecol. Biogeogr. 14: 549-563. doi: 10.1111/j.1466822x.2005.00190.x

Meynier A (1958) Les paysages agraires. Colin, Paris

Mosquera-Losada, MR, Santiago-Freijanes, JJ., Pisanelli, A., Rois-Dı́az, M., et al. (2018) Agroforestry in the European common agricultural policy. Agroforest Syst 92:11171127. doi 10.1007/s10457-018-0251-5

Nair PR (1993) An introduction to agroforestry. Springer Science \& Business Media.

Nardone A, Ronchi B, Lacetera N, et al (2010) Effects of climate changes on animal production and sustainability of livestock systems. Livest Sci 130:57-69. doi:10.1016/j.livsci.2010.02.011

Nissen TM, Midmore DJ, Cabrera ML (1999) Aboveground and belowground competition between intercropped cabbage and young Eucalyptus torelliana. Agrofor Syst 46:83-93. doi: 10.1023/A:1006261627857

Palma JHN, Graves a. R, Bunce RGH, et al (2007) Modeling environmental benefits of silvoarable agroforestry in Europe. Agric Ecosyst Environ 119:320-334. doi: 10.1016/j.agee.2006.07.021

Palombo C (2013) The influence of land-use and climatic changes on mountain pine (Pinus mugo Turra spp. mugo) ecotone dynamics at its southern range margin on the Majella massif, Central Apennines. Ph.D. Dissertation, University of Molise

Paolotti L, Boggia A, Castellini C, et al (2016) Combining livestock and tree crops to improve sustainability in agriculture: A case study using the Life Cycle Assessment (LCA) approach. J Clean Prod 131:351-363. doi:10.1016/j.jclepro.2016.05.024

Pardini A (2009) Agroforestry systems in Italy: traditions towards modern management. In Agroforestry in Europe: current status and future prospects. Rigueiro Rodriguez A, McAdam J, Mosquera Losada MR, (eds), Springer, New York, pp 255-267

Paris P, Buresti E, Cannata F (2001) Agroforestry in Italy. Tradition of the practice and research indications on new models. Proceedings of the Chinese-italian Workshop "Forestry and Agroforestry for Environmental protection and Rural Development", Beijing, China, 2-6 Nov. 1999 
Paris P, Cannata F, Olimpieri G (1995) Influence of alfalfa (Medicago sativa L.) intercropping and polyethylene mulching on early growth of walnut (Juglans spp.) in central Italy. Agrofor Syst 31:169-180. doi:10.1007/BF00711724

Paris P, Olimpieri G, Todaro L, et al (1998) Leaf-water potential and soil-water depletion of walnut mulched with polyethylene and intercropped with alfalfa in central Italy. Agrofor Syst 40:69-81. doi:10.1023/A:1006079215567

Paris P, Perali A, Pisanelli A (2013) Uso di G, area basimetrica, per la modellizzazione dell'interazione tra alberi e colture erbacee consociate in sistemi silvoarabili di noce da legno. Poster. IX Congresso Nazionale SISEF, "Multifunzionalità degli ecosistemi forestali montani", Libera Università di Bolzano/Bozen

Paris P, Pisanelli A, Todaro L, et al (2005) Growth and water relations of walnut trees (Juglans regia L.) on a mesic site in central Italy: Effects of understorey herbs and polyethylene mulching. Agrofor Syst 65:113-121. doi:10.1007/s10457-004-6719-5

Paris P, Tosi L, Leonardi L, Ciolfi M, Della Valle C, Mezzalira G, Sangiovanni M, Lauteri M (2016). Interspecific interactions on the light, water and nitrogen availability in a young poplar silvoarable system. In: Gosme $\mathrm{M}$ et al. [eds], Celebrating 20 years of Agroforestry research in Europe. Book of extended Abstracts of the 3rd European Agroforestry Conference, European Agroforestry Federation. Montpellier, 23-25 May 2016, pagg. 232-235

Pazzagli C (1979) Per la storia dell'agricoltura toscana nei secoli 19 e 20 Dal catasto particellare lorenese al catasto agrario del 1929. Fondazione Luigi Einaudi, Torino

PEFC (2015). https://www.pefc.it/documenti/standardsgestione-forestale-sostenibilepiantagioni-arboree

Perali A (Academic Year 2003/2004) Dissertation thesis: Evoluzione e situazione attuale dei sistemi agroforestali in Italia (con inventario degli impianti monitorati su Cd-rom). Dipartimento di arboricoltura e protezione delle piante. University of Perugia

Pieroni A, Nebel S, Santoro RF, Heinrich M (2005) Food for two seasons: Culinary uses of noncultivated local vegetables and mushrooms in a south Italian village. Int J Food Sci Nutr 56:245-272. doi:10.1080/09637480500146564

Pini R, Paris P, Benetti A, Guidi GV (1999) Soil physical characteristics and understory management in a walnut (Juglans regia L.) plantation in central Italy. Agrofor Syst 46:95105. doi:10.1023/A:1006200310884

Pinto Correia T, Vos W (2005) Multifunctionality in Mediterranean landscapes. Past and future. In: Jongman RHG (ed) The New Dimensions of the European Landscapes. Springer The Netherlands, pp 135-164

Pra A, Brotto L, Mori P, Buresti Lattes E, Polato R, Pettenella D (2016) Redditività finanziaria delle piantagioni da legno. Sherwood 222:11-16

Rackham O, Grove ATG (2003) The Nature of Mediterranean Europe: An Ecological History, Yale University Press

Rao MR, Nair PKR, Ong CK (1997) Biophysical interactions in tropical agroforestry systems. Agroforestry Systems, 38: 3-50

Ronchi B (2009) Rilevanza e prospettive dei sistemi zootecnici silvopastorali. Proceedings of the Terzo Congresso Nazionale di Selvicoltura per il miglioramento e la conservazione dei boschi italiani. 16-19 ottobre 2008, Taormina (Messina), pp. 366-371

Rosati A (2008) Come realizzare una piccola coltivazione di asparago selvatico partendo dal seme. Vita in Campagna 11(2008): 26-29

Rosati A (2011) Asparagi nell'oliveto e la produzione raddoppia. Olivo e Olio 7/8: 20-24

Rosati A (2014) Coltivare asparagi selvatici e allevare polli in un piccolo oliveto. Vita in Campagna 12: 44-48

Rosati A (2001) Un possibile futuro per l'asparago selvatico. L'Informatore Agrario 7: 89-92 
Rosati A, Castellini C, Dal Bosco A, Mugnai C, Paoletti A, Caporali S (2012b) Olive agroforestry: an inverse approach to agroforestry. In "What priorities for European agroforestry", M.R. Mosquera-Losada, A. Pantera, A. Rosati, J. Amaral, J. Smith, C. Dupraz Editors. Book of abstracts of the 1rst European agroforestry conference, 9-10 October 2012, Brusseles. ISBN: 978-84-96351-79-0

Rosati A, Castellini C, Dal Bosco A, Mugnai, Paoletti A (2012a) Manuale per la coltivazione consociata olivo, asparago selvatico, pollo rustico. Edizioni 3A-PTA. ISBN 88-88417-06-0. 87 pagine

Rosati A, Concezzi L, Dal Bosco A, Mugnai C, Paoletti A (2012c) Olivo Asparago selvatico, Pollo rustico. Video on the olive, wild asparagus and free-range chicken system: https://www.youtube.com/watch?v=ALw73WwUr2o. Accessed on march 2017

Rosati A, Falavigna A (2000) Germinazione dei semi di asparago selvatico. L'Informatore Agrario 56/46: 53-55

Rosati A, Piottoli L, Cartoni A, Dal Bosco A, Castellini C (2014) Polli al pascolo nell'oliveto Risparmio a tutto campo. Olivo e Olio 6: 4-7

Rosati A, Pepe R, Senatore A, Perrone D, Falavigna A (2005) Produttività dell'asparago selvatico. L'informatore agrario 8: 75-77

Rosati A, Caporali S, Paoletti A (2009) Olive, Asparagus and animals: an agroforestry model for temperate climate in developed countries. Proceedings of the III OLIVEBIOTEQ (For a renovated, profitable and competitive Mediterranean olive growing sector), Sfax, Tunisia, 15-19 December 2009, ISBN: 978-9938-9513-0-1, 229-233

Rossetti I, Bagella S (2014) Mediterranean Quercus suber wooded grasslands risk disappearance: New evidences from Sardinia (Italy). For Ecol Manage 329:148-157. doi: 10.1016/j.foreco.2014.06.010

Rossetti I, Bagella S, Cappai C, et al (2015) Isolated cork oak trees affect soil properties and biodiversity in a Mediterranean wooded grassland. Agric Ecosyst Environ 202:203-216. doi: 10.1016/j.agee.2015.01.008

Santiago-Freijanes, J.J., Pisanelli, A., Rois-Díaz, M., Aldrey-Vázquez, J.A., Rigueiro-Rodríguez, A., Pantera, A.,, Vityi, A., Lojka, B., Ferreiro-Domínguez, N., Mosquera-Losada, M.R. (2018) Agroforestry development in Europe: Policy issues. Land Use Policy 76: 144-156. doi: 10.1016/j.landusepol.2018.03.014

Santilocchi R, D'Ottavio P (2005) The evolution of cattle and sheep breeding systems in Central Italy over the past two centuries. EAAP Publication 115, pp 15-18

Scherr SJ, Shames S, Friedman R, et al (2012) From climate-smart agriculture to climate-smart landscapes. Agric Food Secur 1:12. doi:10.1186/2048-7010-1-12

Sedda L, Delogu G, Dettori S (2011) Forty-Four Years of Land Use Changes in a Sardinian Cork Oak Agro- Silvopastoral System: A Qualitative Analysis. Open For Sci J 4:57-66

Seddaiu, G., Bagella, S., Pulina, A., Cappai. C., Salis, L., Rossetti, I., Lai, R, Roggerom P.P. (2018). Mediterranean cork oak wooded grasslands: synergies and trade-offs between plant diversity, pasture production and soil carbon. Agroforestry Systems 92:893-908.

Segnalini M, Bernabucci U, Vitali A, et al (2013) Temperature humidity index scenarios in the Mediterranean basin. Int J Biometeorol 57:451-458. doi:10.1007/s00484-012-0571-5

Sereni E (1957) Note per una storia del paesaggio agrario emiliano. In: Zangheri R (ed) Le campagne emiliane nell'epoca moderna. Feltrinelli, Milano

Sestini A (1963) II Paesaggio (Touring club italiano)

Stanislawski D (1970) Landscapes of Bacchus. The Vine in Portugal. University of Texas Press, Austin

Talamucci P, Pardini A, Argenti G, Staglianò N (1995) Functioning of a sylvopastoral system based on different resources, including firebreak lines utilized by sheep. Options Méditerranéennes 12:179-182

Tallarico R, Ghiselli L, Pardini A, Argenti G (2002) Cover in lanes. Acer, 1, 69-73 (In Italian) 
Vallebona C, Mantino A, Bonari E (2016) Exploring the potential of perennial crops in reducing soil erosion: A GIS-based scenario analysis in southern Tuscany, Italy. Appl Geogr 66:119-131. doi: 10.1016/j.apgeog.2015.11.015

Vannucci S (2009) Storia dell'olivo. L'ulivo e l'olio. Bayer CropScience, Milano

Venezia A, Soressi GP, Falavigna A, (1993) Aspetti relativi alla valorizzazione di specie di asparago spontanee in Italia. Agricoltura e Ricerca 141: 41-48

Watson VH, Hagedorn C, Knight WE Pearson HA (1984) Shade tolerance of grass and legume germplasm for use in the southern forest range. J. Range Manag. 37:229-232

Zimmermann RC (1981) Disappearing rural landscapes: a plea for a more systematic pictorial record. Europa (Revue d'Etudes Interdisciplinaires) IV: 267-271

Zimmermann RC (2006) Recording rural landscapes and their cultural associations: some initial results and impressions. Environ Sci Policy 9:360-369. doi:10.1016/j.envsci.2006.01.009

Zohary D, Hopf M (1994) Domestication of plants in the Old World, 2nd edn. Clarendon Press, Oxford, UK 